\title{
Pemilihan Umum dan Pemilihan Presiden dan Wakil Presiden Secara Langsung Perspektif Keumatan (Agama)
}

\author{
Amir Mu'allim
}

If we look back to the era of the Prophet Muhammad PBUH and the Era of Companions, we can find other prespective to see political system which we can compare to the democratic system. In the Islamic context (imamah) there's no specific model to follow, but Islam give more chance and open more space to moslems how to choose their leader. But, the most important point is that Muslim must consider the concept of shura, whereas shura/ musyawarah is been recognized as a core value of democracy.

$\mathrm{B}^{\mathrm{e}}$ elajar dari sejarah pergantian pimpinan pasca Nabi Muhammad saw kiranya dapat menjadi perbandingan model yang akan dilakukan di Indonesia dalam soal pemilu dan pemilihan presiden dan wakil presiden secara langsung. Setidaknya peristiwa pergantian pimpinan yang terjadi pasca meninggalnya Rasulullah saw akan memberikan inspirasi yang secara politis berkaitan erat dengan kondisi bangsa Indonesia.

Empat sahabat yang termasuk Khulafa A)-Rasyidin (Aku Bakar,Umar,Utsman dan Ali) yang sering menjadi rujukan model kepemimpinan bagi umat Islam ternyata tidak satupun proses pemilihannya dilakukan secara langsung oleh rakyat tetapi semuanya melalui sistim perwakilan meskipun dalam mekanismenya sedikit berbeda, dalam konteks ajaran agama (Islam) hal ini tidak mutlak menjadi model yang harus diikuti. Hal ini karena Nabi Muhammad saw sendiri tidak memberi isyarat baik langsung atau tidak langsung dalam kaitannya dalam mekanisme pergantian pimpinan sepeninggai beliau. Mungkin inilah salah satu nilai keuniversalan ajaran Islam di bidang politik khususnya masalah imamah yang memberikan kelonggaran bagi umatnya yang sarat dengan berbagai kepentingan (sosial, budaya, suku, dII).

Fenomena politik membuktikan bahwa setelah 58 tahun Indonesia merdeka dan telah melakukan mekanisme pergantian pimpinan dengan pemilihan umum yang dikenal luber dan pemilihan presiden dan wakil presiden dengan sistem perwakilan akan diubah menjadi pemilu dan pemilihan presiden dan wakil presiden secara langsung sudah barang tentu mempunyai makna tersendiri dengan mempertimbangkan segi positifnya. Akan tetapi terlepas dari prediksi tersebut perlu kiranya dilihat secara filosofis keagamaan tentang kelebihan dan kekurangan sistem pemilu dan pemilihan presiden dan wakil presiden yang akan 
diterapkan di Indonesia dari kacamata kepentingan umat beragama terutama agama Islam. Hal ini menjadi penting karena mayoritas penduduk Indonesia pemeluk agama Islam dan banyak partai-partai yang secara implisit maupun eksplisit menginduk pada label Islam.

Ada tiga persoalan penting yang perlu mendanat perhatian dalam proses pemilu dan pemilihan presiden dan wakil presiden tahun 2004 dalam konteks kepentingan umat beragama yaitu keberagaman partai dalam masyarakat umat beragama, mencermati kualitas masyarakat dan persoalan musyawarah sebagai inti demokrasi. Dengan pembahasan ketiga persoalan ini minimalnya menjadi bahan renungan untuk menghadapi proses pemilu 2004 dalam memasuki era baru.

\section{Keberagaman Partai dalam Masyarakat Umat Beragama}

Maraknya partai peserta pemilu tahun 2004 menandai suburnya era demokrasi yang sedang digulirkan bangsa Indonesia. Terlepas dari visi dan misi apa yang dibangun oleh masing-masing partai akan tetapi setidaknya dengan munculnya banyak partai berarti secara emosional masingmasing pemilik kelompok partai bertekad mengisi dan membangun bangsa Indonesia ke arah yang lebih baik, paling tidak nampak dalam gagasan idenya.

Permasalahan mendasar yang perlu dicermati adalah beberapa partai yang secara inherent memasukkan label keagamaan seperti PKB, PPP, PBB, PAN, dan partai lain dengan misi Islamnya. Sudah barang tentu masing-masing partai memiliki spesifikasi atau keunikan tersendiri terutama dalam menawarkan programnya. Idealnya beberapa partai yang memiliki misi satu agama dapat membangun kekuatan yang sama dan satu persepsi. Hal ini seperti yang difirmankan dalam Al-Quran surat Al Hujurat ayat 13 yang maksudnya "Kami jadikan kamu laki-laki dan perempuan dan Kami jadikan kamu bersuku dan berbangsa agar kamu saling mengenal". Idealnya pesan AlQur'an tersebut menjadi payung dan pegangan dalam menerjemahkan keinginan partai. Artinya pada saat tertentu di mana salah satu partai yang sedang menyampaikan visi misinya hendaklah membawa visi dan misi partai lain atau setidaknya tidak mengganggu dan tidak memperolok-olok visi misi partai lain.

Perbedaan peletakan agama dalam visi dan misi suatu partai politik di Indonesia mulai 1999 hingga 2003 menjelang pemilu 2004 ternyata telah melahirkan banyak partai politik dengan label agama tertentu sebagai identitas. Menjamurnya partai yang berlabel agama itu bagaimanapun membawa masalah dan kebingungan. Sebab sifat pragmatisme berpolitik akan sangat lekat dalam kehidupan partai-partai tersebut. $\mathrm{Hal}$ ini akan menjadikan kesemrawutan antara keyakinan agama dan kepentingan politik (Amir Mu'allim, Jawa Pos, 31 Desember 2003). Dalam kaitan ini eskalasi suhu politik terutama menjelang dan pada saat pemilu 2004 diprediksi meningkat tajam. Kehidupan demokrasi yang belum matang sudah barang tentu tidak hanya mengacak-acak kehidupan beragama yang harmonis tetapi juga menyulut sumber konflik umat beragama dalam satu agama dan umat beragama dengan agama lain. Kehadiran beberapa pemimpin umat dalam partai-partai tertentu dan keberpihakan organisasiorganisasi sosial keagamaan dalam partai tertentu memiliki potensi yang rentan pada terkoreksinya hubungan sosial.

Keberagaman partai yang berlabel Islam secara internal pendidikan politik kurang memperhatikan pengembangan pema- 
haman tentang aspirasi politik umat Islam yang disuarakan. Perbedaan atau keragaman aspirasi politik umat masih belum bisa dipahami secara proporsional dan adil sehingga menimbulkan ketegangan internal serta perlawanan dari aspirasi lain yang sekularistik. Perbedaan aspirasi yang belum bisa dipahami secara proporsional akibat kurangnya pendidikan politik pada gilirannya mengabaikan aspirasi agama yang bersifat universal yang menjadi dambaan setiap orang. Kebetulan juga sesuai dengan tujuan berdirinya negara RI yaitu kesejahteraan dan keadilan untuk seluruh rakyat (Tosari Widjaja, Jawa Pos 19 Januari 2004).

Keberadaan partai politik dalam posisinya sebagai penyelamat pemilu sangat penting karena secara dejure partai politiklah yang mendapat legalitas hukum dalam tatanan politik di Indonesia sebagaimana disebutkan dalam pasal $22 \mathrm{E}$ ayat (3) UUD 1945 hasil Amandemen yang menyatakan bahwa "Peserta pemilihan umum untuk memilih anggota Dewan Perwakilan Rakyat dan anggota Dewan Perwakilan Rakyat Daerah adalah partai politik" (Sinar Grafika, 2003:15).

Secara filosofis sebenarnya payung pemersatu sebagai bingkai penyelamat bangsa Indonesia sudah ada sejak diproklamirkannya bangsa Indonesia yaitu dengan slogan Bhineka Tunggal lka yang dilambangkan dalam Garuda Pancasila dan Persatuan Indonesia yang tercermin dalam Pancasila sebagai dasar negara. Kedua payung ini secara bahas̈a dan isi sudah cukup netral, artinya payung itu dapat dipakai dalam agama apapun, golongan apapun, suku apapun dan partai politik apapun. Hanya'kenyataan di lapangan penerapan istilah Bhineka Tunggal lka dan Persatuan Indonesia menjadi sangat subyektif, artinya penerapan kedua simbol tersebut menjadi versi agama tertentu, golongan tertentu, suku tertentu dan partai politik tertentu yang akhirnya menjurus pada aspek kepentingan.

Contoh konkret perubahan penafsiran tersebut nampak pada waktu partai tertentu mengadakan kampanye. Bendera yang dibawa sebagai simbol kepemilikan partainya selalu menjadi idola dan seolaholah sebagai simbol suci yang tidak boleh dinodai oleh siapapun. Sebaliknya apabila melihat bendera lain selain milik partainya meskipun bendera itu milik partai seagama dianggapnya sebagai bendera milik musuh apalagi bendera itu tidak bernaung pada partai yang memiliki identitas agama tertentu. Celakanya kalau sudah sampai pada taraf teori balas dendam. Semisal partai tertentu menyobek atau membakar bendera milik partai lain kemudian partai yang benderanya disobek atau dibakar kemudian membalasnya.

Sebagai solusi untuk mengurangi arogansi tindakan sepihak maka perlu disuburkan toleransi antar umat beragama dengan cara menghormati perbedaan, mengembangkan persaudaraan, menjalin kerjasama, tidak mencela partai lain dan tidak mempolitisir agama serta senantiasa berusaha mencari persamaan dan tidak membedakan perbedaan yang ada. Dengan kata lain bagaimana memandang keberagaman dan perbedaan itu sebagai rahmat seperti yang dipesankan Nabi Ikhtilafu ummati rahmatun (H.R. Muslim). Di samping itu dalam rangka mengembangkan kerukunan antar umat beragama " dan kerukunan partai perlu diperkuat keberadaan majelis antar umat beragama, sebagai wahana komunikasi antar umat untuk menjembatani dan memecahkan persoalan yang timbul di antara umat beragama terutama lapisan masyarakat bawah. 


\section{Mencermati Kualitas Masyarakat}

Bangsa Indonesia adalah salah satu di antara bangsa yang memiliki potensi besar sumber daya alam dan sumber daya manusia dengan jumlah penduduknya yang di atas 200 juta jiwa. Persoalan mendasar adalah menyangkut kualitas masyarakat itu sendiri. Kualitas yang dimaksud tidak sekedar kualitas intelektual tetapi juga kualitas moral. Berbagai kasus para pejabat 'negara baik yang sudah atau sedang diproses aparat penegak hukum menandakan kualitas moral bangsa Indonesia yang tidak mencerminkan sebagai bangsa yang luhur. Merebaknya isu dan kasus ijazah palsu bagi calon legislatif seperti yang diinformasikan berbagai media massa serta money politics (politik uang) yang dilakukan oleh sejumlah calon pemegang kekuasaan, bahkan ada calon yang gagal dalam pemilihan kepala daerah (Pilkada) secara terus terang telah melakukan praktek politik uang. Semua itu menandakan kualitas sumber daya manusia terutama dalam hal politik uang yang begitu rapuh. Kalau dalam kelompok yang memiliki kualitas keintelekan saja seperti itu apalagi kelompok di tingkat bawah yang tidak mustahil akan terjadi kerapuhan dalam mempertahankan komitmen kebenaran, kejujuran dan keadilan.

Dalam teori analog (Qiyas Aulawy) kalau orang yang tingkat ekonominya mencukupi itu saja bisa main politik uang apalagi orang yang ekonominya rendah. Artinya orang yang taraf kehidupan ekonominya paspasan akan lebih banyak peluang untuk melakukan politik uang. Padahal menurut data sementara 40 juta penduduk Indonesia masuk dalam kategori menganggur. Ini berarti kualitas ekonomi sumber daya manusia masih tergolong lemah. Sinyalemen hadis Nabi yang menyatakan bahwa kefakiran akan membawa kekufuran bukan sesuatu yang utopis tetapi sudah sampai pada kenyataan. Artinya dengan banyaknya pengangguran akan cepat mencari jalan pintas dengan menghalalkan segala cara.

Dalam kaitan ini maka pemilihan umum yang akan dilangsungkan di Indonesia secara langsung tidak mustahil akan membuka pelue:: $y$ praktek politik uang yang lebih dari sekedar politik uang yang dilakukan pada waktu pilkada (Pemilihan Kepala Daerah). Kalau ini terjadi maka dambaan bangsa Indonesia menjadi bangsa yang mencerminkan keluhuran dan berkualitas hanya sekedar impian belaka. Padahal secara agama praktek politik uang bisa masuk kategori riswah (sogok menyogok) dan orang yang melakukannya (dua-duanya) masuk neraka.

Berbagai pihak sangat mengharapkan agar wakil rakyat yang dipilih dapat membawa nama harum bangsa dan dapat mengeluarkan dari segala krisis, seperti harapan baru rakyat yang ditulis dalam tajuk rencana Suara Muhammadiyah antara lain berpesan bahwa di pundak para anggota DPR, DPD dan Presiden serta Wakil Presiden dari hasil pemilu 2004 itulah terletak nasib politik bangsa ini. Kita berharap denyut harapan dan persoalan yang dihadapi rakyat Indonesia yang menggunung itu benar-benar dihayati dan menjadi komitmen para elit nasional hasil pemilu 2004 itu. Di pundak mereka terletak kewajiban untuk menyelamatkan bangsa ini dari kehancuran. Mereka berkewajiban untuk memanfaatkan kekuasaannya untuk berhikmat kepada rakyat dan kepentingan bangsa.

Mereka yang tidak berniat dan berkemampuan untuk menanggung beban rakyat dan negara yang berat itu maka lebih baik sejak saat ini mundur dan tidak meneruskan pencalonannya sebagai calon anggota DPR, DPD, Wakil Presiden dan 
Presiden. Berikan peluang kepada mereka yang memiliki komitmen dan kesanggupan serta kemampuan yang tinggi untuk berhikmat bagi rakyat dan negara. Jangan berikan peluang politik yang mulia itu pada elit-elit pemulung dan aji mumpung. Kepada rakyat kita berharap.jangan sekali-kali salah pilih lagi (Suara Muhammadiyah No.01 Tahun ke 89).

Harapan baru rakyat tersebut mewakili lebih dari 200 juta rakyat Indonesia untuk mewujudkan bangsa Indonesia dari keterpurukan: Rakyat Indonesia diharapkan tidak terjebak dengan kenikmatan dan kesenangan sesaat yang akibatnya akan menjebak nasib dirinya sendiri. Pengalaman pahit sejarah yang hanya sekedar bermain uang sudah bisa dibaca dalam kenyataan dan sekarang sudah saatnya untuk memulai babak baru untuk menuju Indonesia baru yang lebih cemerlang baik dalam skala nasional maupun internasional.

\section{Musyawarah Sebagai Inti Demokrasi}

Istilah demokrasi yang sedang menggema terutama dalam suasana menjelang dan pada saat pemilu menjadi sangat penting untuk dicermati karena pemilu sering diidentikkan dengan pesta demokrasi. Dalam kaitan ini rakyat sebagai subjek dan sekaligus sebagai objek pesta demokrasi harus dipahamkan tentang makna dan tujuan demokrasi agar tidak salah langkah.

Secara sederhana makna demokrasi adalah bentuk atau sistem pemerintahan yang segenap rakyat turut serta memerintah dengan perantara wakilnya (Kamus Umum Bahasa Indonesia :82). Rumusan sederhana ini secara filosofis mengandung arti bahwa dalam menerapkan sistem demokrasi - keterwakilan menjadi acuan utama.
Penerjemahan terminologi demokrasi ini sebetulnya sudah cukup bagus dilaksanakan pemilu sebelumnya karena dengan pola keterwakilan berarti secara kualitas lebih dapat dipertanggungjawabkan.

Kelebihan sistem pemilu yang lalu dengan keterwakilan partai dan keterwakilan unsur lain yang mendukung kiranya lebih akomodatif, di szmping mekanisme yang tidak berbelit-belit. Dengan sistem keterwakilan terutama untuk memilih presiden dan wakil presiden lebih dijamin kualitasnya karena penjaringan orang-orang yang akan dipilih menjadi presiden dan wakil presiden dilakukan oleh orang-orang yang terpilih. Keterwakilan tidak mungkin dapat terwujud tanpa adanya musyawarah. Oleh karena itu dalam kaitan demokrasi masalah musyawarah menjadi sangat penting dan menjadi inti dari demokrasi.

Rakyat Indonesia yang mayoritas penduduknya memeluk agama Islam patut merenungkan pesan-pesan Al-Quran tentang pentingnya musyawarah. Seperti ayat 159 surat Ali Imran yang maksudnya "Maka disebabkan rahmat dari Allahlah kamu berlaku lemah lembut terhadap mereka. Sekiranya kamu bersikap keras lagi berhati kasar tentulah mereka menjauhkan diridari sekeliingmu. Karena itu maafkanlah mereka, mohonkanlah ampun bagi mereka dan bermusyawarahlah dengan mereka dengan urusan itu. Kemudian apabila kamu telah membulatkan tekad maka bertawakkallah kepada Allah Sesungguhnya Allah menyukai . orang-orang yang bertawakkal kepadaNya". - Demikian pula ayat 38 surat Asy Syura yang maksudnya "Dan (bagi) orang-orang yang menerima (mematuhi) seruan Tuhannya dan mendirikan shalat, sedang urusan mereka (diputuskan) dengan musyawarah antara mereka dan mereka menafkahkan sebagian dari rezeki yang Kami berikan kepada mereka". 
Sukseși pengangkatan empat khalifah atau yang dikenal dengan istilah Al Khulafa Al-rasyidin setelah Rasulullah saw wafat keseluruhannya juga dilakukan dengan prinsip musyawarah meskipun dengan versi yang beragam.

Abu Bakar menjadi khalifah yang pertama melalui pemilihan dalam satu pertemuan yang berlangsung pada hari kedua setelah Rasulullah wafat. Penunjukan Abu Bakar sebagai khalifah didahului dengan adu argumentasi oleh tokoh-tokoh terpercaya seperti Umar, Abu Ubaidah bin Jarrah, Basyir bin Saad, Asid bin Khudair dan Salim di samping Abu Bakar sendiri yang akhirnya terjadi kesepakatan yang ditandai dengan pembaiatan terhadap Abu Bakar yang dikenal dengan Baiat Saqifah atau Baiat di balai pertemuan (Munawir Sjadzali, 1990;22-23).

Pembaiatan Abu Bakar sebagai khalifah dipertegas ulasan Ali As-'Salus yang "menyitir" kata-kata Umar r.a. bahwa janganlah ada orang yang terpedaya hingga ia mengatakan bahwa pembaiatan itu tergesa-gesa.dan telah selesai. Ketahuilah bahwa pembaiatan itu memang demikian dan Allah telah mencegah terjadinya keburukan. Dan siapa yang membaiat seseorang tanpa musyawarah umat Islam maka pembaiatan itu tidak benar dan orang yang membaiat maupun yang dibaiat dapat dibunuh. Sesungguhnya Abu Baḱar adalah orang yang terbaik di antara kita ketika Rosulullah wafat (Ali As-Salus, 1997;19-20).

Umar r.a. meskipun naiknya khalifah melalui penunjukan Abu Bakar tetapi dari penunjukan itu akhirnya dimusyawarahkan oleh tim kecil yang termasuk senior seperti Abdurrahman bin Auf, Utsman bin Affan dan Asid bin Khudair.

Utsman bin Affan menduduki khalifah melalui penunjukan enam orang senior oleh Umar r.a. yang akhirnya enam orang sepakat menunjuk Utsman bin Affan sebagai khalifah demikian halnya Ali bin Abi Thalib naiknya menjadi khalifah juga dengan prinsip musyawarah yang didahului dengan pembaiatan dari tokoh-tokoh terkenal pada masanya.

Bercermin dari mekanisme pemilihan empat khalifah tersebut mengisyaratkan akan pentingnya sistem perwakilan dalam pemilihan kepala negara atau presiden. Karena dengan system perwakilan orangorang yang akan mewakili sudah melalui uji kelayakan. Dalam konteks pemilihan presiden dan wakil presiden akan ditentukan dan dipilih oleh orang-orang yang terpilih. Penerapan mekanisme seperti ini sebagai upaya menghindari masuknya orang-orang yang tidak memiliki kepantasan menduduki jabatan presiden dan wakil presiden. Dan inilah kelebihan hadis $\mathrm{Nabi}$ yang menyatakan bahwa apabila perkara itu diserahkan kepada orang yang bukan ahlinya maka tunggulah kehancurannya (H.R. Bukhari dan Muslim).

Mulyana W. Kusumah menyitir katakata Waih Andrew Elvis, Senion Advison ND/ (2002) tentang pemilihan presiden secara langsung putaran kedua untuk memilih salah satu di antara dua pasangan calon yang memperoleh suara terbanyak pertama dan kedua kemungkinan dapat "membelah" bangsa ke dalam dua kutub yang berseberangan, terutama bila pasangan calon dan proses pendudukannya tidak mengindahkan aturan-aturan pemilihan di puncak persaingan dalam pemilu. Ini mungkin terjadi dalam masa kampanye yang panjang (Mulyana W. Kusumah, Kompas, 7 Agustus 2002).

Permasalahan yang mendasar tentang pemilihan umum dan pemilihan presiden dan wakil presiden secara langsung bagi rakyat dan lebih khusus bagi umat beragama adalah belum siapnya bagi yang kalah untuk 
menerima kekalahan. Hal ini terbukti dalam kasus pilkada di mana masa yang kalah akhirnya berulah dan melakukan sesuatu yang tidak semestinya dilakukan dengan berbagai tindakan anarkis.

Oleh karena itu upaya preventif yang harus dilakukan para elit partai pemilu adalah menyadarkan masa untuk siap menerima kekalahan dan siap mendukung yang menang, meskipun hal ini tidak menjamin kelancaran dan ketenangan pada saat dan pasca pemilu 2004. Berbagai usaha preventif harus dicoba dilakukan atau cialam istilah agama Islam dikenal dengan istilah Saddu Dzari'ah (Menutup jalan yang menuju kerusakan).

\section{Kesimpulan}

Model pemilu 2004 yang akan diterapkan di Indonesia masih penuh tekateki apakah dengan model dan cara baru dengan sistem pemilu dan pemilihan presiden dan wakil presiden yang langsung akan lebih baik dan membawa dampak positif bagi kelanjutan bangsa atau malah sebaliknya. Persoalan ini sangat penting untuk dicermati karena kebanyakan rakyat Indonesia berdasar pengalaman tentang pilkada dan proses pencalegan banyak halhal dan kejadian yang tidak pantas untuk dilakukan. Dan lagi rakyat Indonesia tidak siap kalah, dan selalu ingin menang, oleh karena itu perli upaya-upaya preventif dan sikap arif yang harus dimiliki oleh semua lapisan masyarakat agar tidak terjadi halhal yang tidak diinginkan.

Karena mayoritas penduduk Indonesia beragama Islam, maka tugas utama bagi para elit politik dan mereka yang akan diposisikan sebagai wakil rakyat agar mampu menyadarkan masyarakat untuk dapat bersikap arif dalam menyikapi pemilu agar pemilu 2004 yang akan datang betulbetul menjadi cermin dan contoh pemilupemilu berikutnya.

\section{Daftar Pustaka}

Kamus Umum Bahasa Indonesia, Bandung

Kusumah, Mulyana W. "Pemilihan Presiden RI, 2004," Kompas, 7 Agustus 2002

Mu'allim, Amir. Kehidupan Agama yang Terkoreksi, Jawa Pos, Rabu 31 Desember 2003.

Nawawi, Abu Zakariya Yahya ibnu Syarif ibnu Maria; 1392 H. Sahih Muslim Syarh An Nawawi, Beirut: Dar Ihya alTuras Al Arobi.

Salus, Ali As, 1997, Imamah dan Khilafah dalam Tinjauan Syari. Jakarta: Gema Insani Press.

Sinar Grafika, 2002. UUD 1945 Hasil Amandemen \& Proses Amandemen UUD 1945 secara lengkap (Pertama 1999-keempat 2002). Jakarta: Sinar Grafika.

Sjadzali, Munawir. 1990, Islam dan Tata Negara: Ajaran Sejarah dan Pemikiran, Jakarta: UI Press.

Suara Muhammadiyah, Tajuk Rencana Harapan Baru Rakyat, No.1 Th. 1989.

Widjaja, Tosari. "Agama dan Isu-isu Kampanye," Jawa Pos, Senin, 19 Januari 2004.

Departemen Agama RI, 1971, Al Qur'an dan Terjemahnya. Jakarta: CV. Kathoda. 